OPEN ACCESS

Edited by:

Hehuang Xie,

Virginia Tech, United States

Reviewed by:

Daniel Vaiman,

Institut National de la Santé et de la Recherche Médicale (INSERM), France

Sergey Razin,

Institute of Gene Biology (RAS), Russia

*Correspondence:

Selene L. Fernandez-Valverde selene.fernandez@cinvestav.mx

Specialty section:

This article was submitted to Epigenomics and Epigenetics,

a section of the journal

Frontiers in Genetics

Received: 31 July 2020 Accepted: 09 November 2020

Published: 30 November 2020

Citation:

Ramírez-Colmenero A, Oktaba K and

Fernandez-Valverde SL (2020)

Evolution of Genome-Organizing

Long Non-coding RNAs

in Metazoans.

Front. Genet. 11:589697.

doi: 10.3389/fgene.2020.589697

\section{Evolution of Genome-Organizing Long Non-coding RNAs in Metazoans}

\author{
América Ramírez-Colmenero', Katarzyna Oktaba ${ }^{2}$ and Selene L. Fernandez-Valverde ${ }^{1 *}$ \\ 'Unidad de Genómica Avanzada (Langebio), Centro de Investigación y de Estudios Avanzados del IPN, Irapuato, México, \\ 2Unidad Irapuato, Centro de Investigación y de Estudios Avanzados del IPN, Irapuato, México
}

Long non-coding RNAs (IncRNAs) have important regulatory functions across eukarya. It is now clear that many of these functions are related to gene expression regulation through their capacity to recruit epigenetic modifiers and establish chromatin interactions. Several IncRNAs have been recently shown to participate in modulating chromatin within the spatial organization of the genome in the three-dimensional space of the nucleus. The identification of IncRNA candidates is challenging, as it is their functional characterization. Conservation signatures of IncRNAs are different from those of protein-coding genes, making identifying IncRNAs under selection a difficult task, and the homology between IncRNAs may not be readily apparent. Here, we review the evidence for these higher-order genome organization functions of IncRNAs in animals and the evolutionary signatures they display.

Keywords: evolution, conservation, long-non-coding RNAs, chromatin conformation, three-dimensional chromatin conformation, genome topology, gene expression regulation

\section{INTRODUCTION}

The three-dimensional (3D) organization of DNA in the cell nucleus has become a significant subject of study, particularly its influence on gene regulation. Recent advances in chromatin conformation capture (3C) techniques, computational, and modeling approaches have made its study feasible on a genome-wide scale, giving insight into the structure and the dynamics of chromatin folding in space and time. Nuclear 3D organization has multiple levels and varies between cell types and biological conditions. For instance, chromosomes are subdivided into topologically associating domains (TADs) within which chromatin loops bring together regulatory elements and target loci separated in the linear genome (Dixon et al., 2012). These chromatin interactions are crucial for precise gene expression regulation (reviewed in Furlong and Levine, 2018; Schoenfelder and Fraser, 2019; Ibrahim and Mundlos, 2020). Importantly, changes in transcriptional programs result in variation in chromatin interactions within TADs, while TAD boundaries delimiting these domains are preserved (Dixon et al., 2015). TADs segregate in the nuclear space into transcriptionally active (A) and inactive (B) compartments. A/B compartments correlate well with histone modifications characteristic of euchromatin and heterochromatin, respectively, and are described as cell type-specific, being able to undergo switches during cell differentiation and lineage commitment (Lieberman-Aiden et al., 2009; Rao et al., 2014; Dixon et al., 2015; Fortin and Hansen, 2015). 
In addition to DNA and histones, RNA is a major component of the cell nucleus (Rinn and Chang, 2012). High-throughput sequencing methods have revealed the pervasive transcription of thousands of non-coding RNA (ncRNA) molecules in the genome. Among the latter, long non-coding RNAs (lncRNAs) have emerged as important gene regulators in eukaryotes. lncRNAs are broadly defined as transcripts longer than 200 nucleotides, with little to no protein-coding potential (Mercer et al., 2009; Wang and Chang, 2011; Derrien et al., 2012). lncRNAs are more lowly expressed (Hezroni et al., 2015), display more tissue-restricted expression patterns (Necsulea et al., 2014), have fewer exons, and are shorter than proteincoding genes (Hezroni et al., 2015). In animals, several lncRNAs are essential to phenomena such as gene silencing, activation, and chromatin remodeling, with significant roles in development, immunity, and cancer (Guttman et al., 2011; Schmitt and Chang, 2016; Delás et al., 2017). IncRNA functions may predate the origin of metazoans, as several unicellular holozans possess lncRNAs that are distinct in terms of their histone marks as well as expression throughout their life cycle (Gaiti et al., 2017).

\section{SIGNATURES OF CONSERVATION IN LNCRNAS}

There has been a long debate on whether most lncRNAs are functional or not (van Bakel et al., 2010; Clark et al., 2011; Lindsay et al., 2013). This discussion was, in part, sparked by the fact that the sequence of $\operatorname{lncRNAs}$ is generally poorly conserved across species, suggesting that they are not under purifying selection (Babak et al., 2005; Ponjavic et al., 2007; Marques and Ponting, 2009). There are several examples of orthologous RNAs that preserve their function, but whose sequence is so divergent, they can no longer be identified as orthologs by sequence similarity alone (Ponjavic et al., 2007; Ulitsky et al., 2011; Ulitsky, 2016). Thus, the detection of conservation beyond sequence is paramount to annotate candidate lncRNAs for further functional characterization.

The conservation signals in lncRNAs can differ from those typically found in protein-coding genes (Diederichs, 2014; Ulitsky, 2016). For instance, conventional conservation analyses applied to coding sequences, such as calculating the rate between synonymous and non-synonymous mutations, are not suitable for these elements. Nevertheless, lncRNAs display some sequence conservation, generally in short sequence islands, potentially due to selection constraints on sequences necessary for interacting with other transcripts, proteins, or DNA (Kapusta and Feschotte, 2014; Quinn et al., 2016; Ulitsky, 2016). IncRNAs may also display constraints on the post-transcriptional processing of the transcript, leading to the conservation of splice sites across different species (Nitsche et al., 2015; Ulitsky, 2016). lncRNAs can also possess structural conservation - a constraint that may not be readily detectable at the sequence level (Smith et al., 2013; Tavares et al., 2019). Finally, lncRNAs can have positional conservation, and be expressed from syntenic loci despite having lost most or all sequence conservation.
These modes of conservation are not mutually exclusive and may be present in a single lncRNA.

Beyond their apparent lack of conservation, many functionally characterized IncRNAs modulate the organization of higherorder chromatin structures in the nucleus (Saxena and Carninci, 2011; Marchese and Huarte, 2014). IncRNAs are involved in the formation of DNA loops and domains (Wang and Chang, 2011; Zhang et al., 2014), interchromosomal structures (Hacisuleyman et al., 2016), heterochromatic regions (Deng et al., 2009; Engreitz et al., 2013), subnuclear bodies (Mao et al., 2011), and the dynamic assembly of protein complexes (Tsai et al., 2010; Lin et al., 2014; Marín-Béjar et al., 2017). Several novel experimental methods allow the identification of IncRNAs binding to chromatin in vivo across the genome (Li et al., 2017; Sridhar et al., 2017; Bell et al., 2018; Bonetti et al., 2020; Gavrilov et al., 2020). Recruiting and binding to effector molecules is a prevalent mode of action of lncRNAs in both cis and trans activities.

Here, we summarize lncRNAs that affect, establish, or maintain three-dimensional chromatin organization in metazoans and the conservation signals that indicate they are under selection.

\section{LNCRNAS THAT AFFECT TAD CONFORMATION AND THEIR CONSERVATION}

\section{Sequence Conservation}

Sequence conservation in lncRNAs can range from very high to almost non-existent. Despite being generally presented as poorly conserved, a subset of lncRNAs can present significant sequence conservation across species (Necsulea et al., 2014; Hezroni et al., 2015). However, sequence conservation does not guarantee functional equivalence; a highly conserved lncRNA can be fundamental in one species while dispensable in others. For example, the IncRNA Metastasis Associated in Lung Adenocarcinoma Transcript 1 (MALAT1) is highly conserved from human to zebrafish (Figure 1A; Hutchinson et al., 2007; Lin et al., 2007). While the human MALAT1 functions in nuclear speckles, regulating alternative splicing (Hutchinson et al., 2007; Tripathi et al., 2010), cell-cycle associated genes (Yang et al., 2011), and cancer progression (Gutschner et al., 2013), the murine ortholog is neither essential for these functions nor mouse development (Eißmann et al., 2012; Nakagawa et al., 2012; Zhang et al., 2012).

However, it is more common for lncRNAs to have short conserved motifs or domains that are important for their association with DNA or proteins that regulate chromatin conformation. For example, lncRNAs that affect 3D genome topology and arise from highly conserved syntenic loci, such as the Hox clusters, display contrasting patterns of sequence conservation compared to their protein counterparts in the same cluster. Hox genes, organized in mammals in four clusters (HoxA-HoxD), encode transcription factors crucial for patterning along the anterior-posterior axis. Numerous ncRNAs are 
A

Type of conservation

Sequence conservation

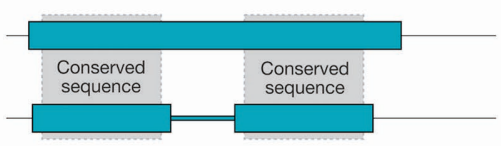

B

\section{Positional conservation (synteny)}

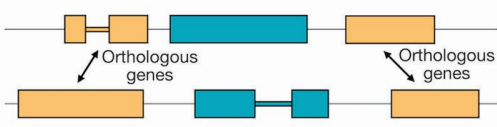

C

\section{Structural conservation}

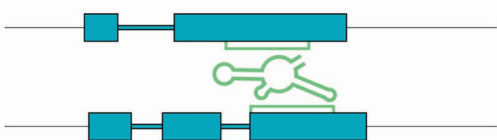

D

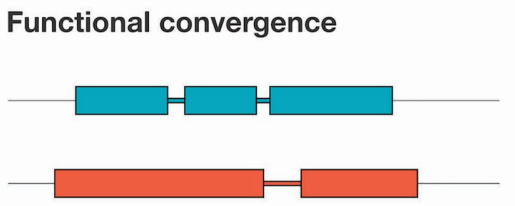

Example IncRNA

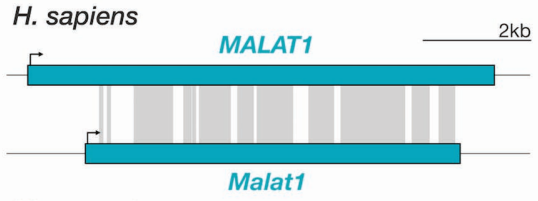

M. musculus

\section{Mechanism of action}

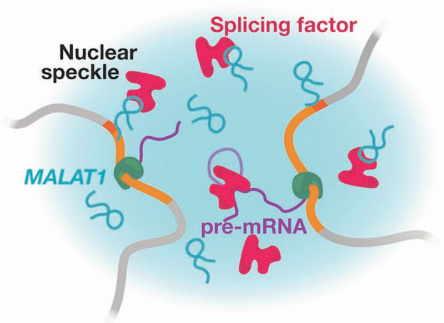

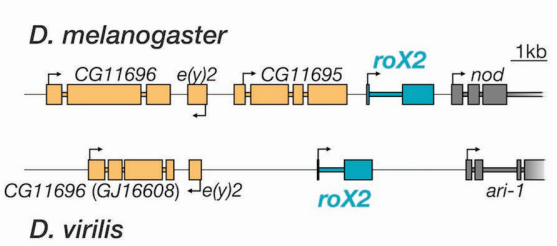

D. virilis

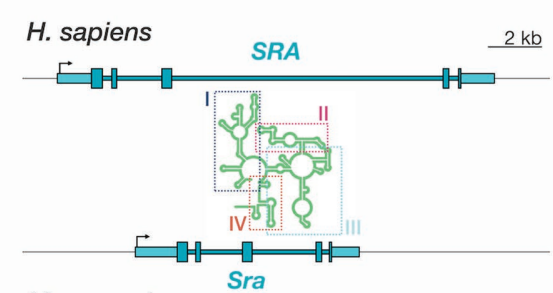

M. musculus

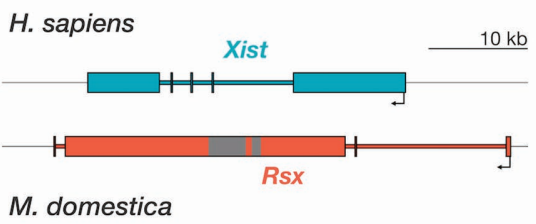

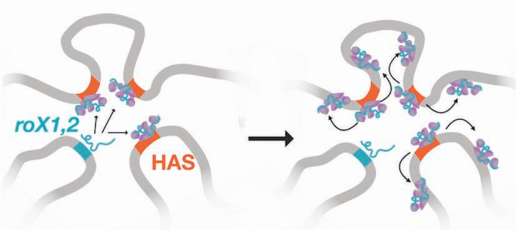

23: MSL Complex
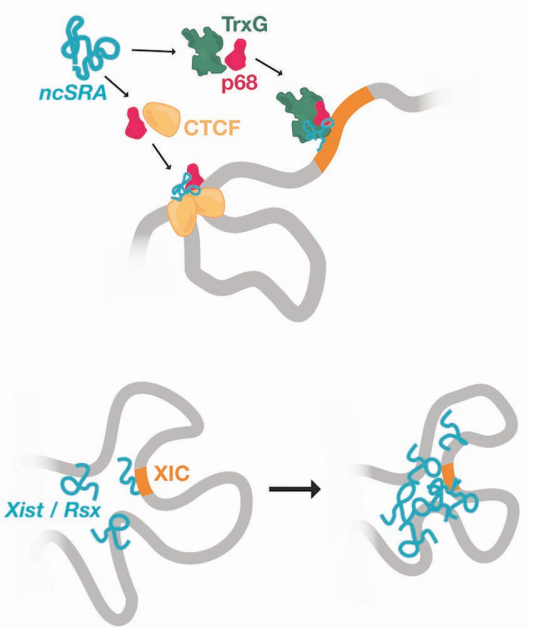

FIGURE 1 | Types of conservation and mechanism of action of example IncRNAs. Diagrams show exons (big filled boxes) and introns (colored links) of IncRNAs genes. 5' and 3' UTRs are shown as light blue boxes in (C). (A) Sequence conservation: Some IncRNAs present high levels of sequence conservation (gray shading). For example, the Metastasis Associated in Lung Adenocarcinoma Transcript 1 (MALAT1) IncRNA is highly conserved from human to zebrafish. Regions of conservation are shown according to the "Vertebrate Multiz Alignment \& Conservation" track of the UCSC genome browser. MALAT1 localizes to nuclear speckles, nuclear bodies for co-transcriptional and post-transcriptional pre-mRNA processing. In humans, MALAT1 regulates the phosphorylation of serine/arginine splicing factors, enriched at nuclear speckles. (B) Positional conservation: IncRNAs can have a conserved genomic position but very low sequence conservation. This is the case for the roX IncRNAs in Drosophila, identified by a combination of synteny, microhomology, and secondary structure. roX1 (not shown) and roX2 spread to highaffinity sites (HASs), landing regions of male-specific lethal (MSL) complex, in close spatial proximity, regulating local chromatin remodeling, leading to the increased expression of genes for dosage compensation. (C) Structural conservation: IncRNAs can fold into a conserved secondary structure. The steroid receptor RNA activator (SRA) gene produces both a protein and a IncRNA (ncSRA). A simplified representation of the structure of the human ncSRA, as determined by Novikova et al. (2012), is depicted. ncSRA consists of four main domains, three of which are well-conserved at sequence across 36 vertebrate species and contain covariant base pairs. Different segments of the structure have differences in sequence conservation, and specific helices are highly conserved. ncSRA binds to several proteins including: trithorax group (TrxG), DEAD-box RNA helicase 5 (DDX5 or p68), and CCCTC-binding factor (CTCF), potentially acting as a scaffold for the assembly of ribonucleoprotein complexes. (D) Functional convergence: IncRNAs with no common origin can have an equivalent function. The $X$-inactive specific transcript (Xist) and RNA on the silent X (RsX) IncRNAs act on the process of dosage compensation in different species. Both Xist and RsX are expressed form the $X$ inactivation center $(X \mid C)$ and are spread along the $X$ chromosome to inactivate it.

transcribed from the human HOX loci, and their expression relates to differential histone marks and transcriptional accessibility (Rinn et al., 2007).
The HOX antisense intergenic RNA (HOTAIR) lncRNA is transcribed from the boundary between domains with differential chromatin marks at the $\mathrm{HOXC}$ locus but acts in trans repressing 
transcription of coding and non-coding genes on the HOXD locus (Rinn et al., 2007). A chromatin loop established between HOTAIR locus and the HOXC distal enhancer (HDE) located downstream of HOTAIR promotes transcription of the lncRNA. This loop is disrupted by the recruitment of hepatocyte nuclear factor $4-\alpha$ (HNF4 $\alpha)$, a master regulator of epithelial differentiation, to the HDE (Battistelli et al., 2019). HOTAIR exists across mammals, albeit poorly conserved in sequence; it is only highly conserved in primates (He et al., 2011). Noteworthy, a highly conserved domain in exon 6, possibly the backbone of HOTAIR, appeared first in kangaroos suggesting the $a b$ initio generation of HOTAIR in marsupials (He et al., 2011). Despite its low sequence conservation across mammals, key secondary structural elements of HOTAIR contain proteinbinding motifs and have significant conservation or covariation (He et al., 2011; Somarowthu et al., 2015). However, studies evaluating the functional conservation of murine HOTAIR ( $m$ Hotair) present contradictory results. On the one hand, the deletion of the HoxC cluster, including mHotair, did not affect HoxD silencing in vivo (Schorderet and Duboule, 2011). In contrast, mice homozygous for mHotair KO presented homeotic spine transformation and malformation of metacarpal bones, and derived fibroblasts showed altered expression and levels of epigenetic marks at hundreds of genes, including HoxD genes (Li et al., 2013). Interestingly, human and mouse HOTAIR differ in number, arrangement, and degree of sequence conservation among their exons. The absence of exons with protein-binding motifs in mHotair may partially explain differences in their function.

Another lncRNA expressed from HOX clusters is HOXA transcript at the distal tip (HOTTIP), transcribed from the 5 ' end of the HOXA locus in mammals and conserved in avians (Wang et al., 2011). Chromosomal looping brings HOTTIP into spatial proximity to its target genes in cis, allowing HOTTIP to activate transcription by binding the WD repeat domain 5/mixed lineage leukemia (WDR5/MLL) complex, driving H3K4me3 (Wang et al., 2011). HOTTIP and its association with CCCTC-binding factor (CTCF), which delineates active and inactive TADs within the HOXA cluster, also influence the expression of HoxA genes (Narendra et al., 2015; Wang et al., 2018).

Long non-coding RNAs also enable the establishment of inter-chromosomal structures. The Functional intergenic repeating RNA element (Firre) is a lncRNA involved in pluripotency, hematopoiesis, and adipogenesis (Hacisuleyman et al., 2014; Lewandowski et al., 2019). Firre accumulates across a $\sim 5 \mathrm{Mb}$ domain around its transcription site on the X chromosome (Hacisuleyman et al., 2014), located between two TADs, and highly enriched in CTCF binding sites, required for Firre transcription (Barutcu et al., 2018). This domain colocalizes with five regions on different chromosomes that contain genes with roles in adipogenesis. The formation of this structure depends on the interaction of Firre with Heterogeneous Nuclear Ribonucleoprotein U (HNRNPU), through a 156-bp repeating RNA domain (RRD; Hacisuleyman et al., 2014). This RRD is unique to Firre, and functions as a lineage-specific nuclear retention signal in mice and humans.
The RRD and other local repeats (LRs) are conserved to different extents across Firre orthologs in mammals. Firre is also required for the super-loop formation of the inactive $\mathrm{X}$ chromosome (Xi), H3K27me3 deposition, and the localization of the $\mathrm{Xi}$ to the perinuclear region (Yang et al., 2015; Barutcu et al., 2018).

The 3D architecture of TADs enables a group of multiexonic lncRNAs, termed immune gene-priming lncRNAs (IPLs), to direct the active priming of the promoters of immune genes, necessary for a rapid and robust pro-inflammatory response as part of trained immunity (Fanucchi et al., 2019). Upon induction of transcription of immune genes by the tumor necrosis factor (TNF), chromatin contacts increase TNF-induced genes and the lncRNAs loci. IPLs are somewhat conserved between mouse and human; the majority possess an Alu element in their first intron and share putative transcription-factor binding motifs at their promoters.

The region comprising an IPL, Upstream master IncRNA of the inflammatory chemokine locus (UMLILO), engages in chromosomal contacts with CXCL chemokine genes belonging to the same TAD, but UMLILO does not have enhancer-RNAlike characteristics. In contrast to other IPLs, UMLILO is not conserved in mice and only partially conserved in pigs, suggesting that IPLs are not essential across species, but have a complementary role in ensuring robust gene expression. UMLILO has short conserved sequence motifs and interacts with WDR5 through its conserved exon 3, directing WDR5/MLL1 to chemokine gene promoters, mediating H3K4me3. Transcription of chemokines in UMLILO knockdown cells was restored by insertion of another WDR5-binding lncRNA, HOTTIP, under the control of the UMLILO promoter (Fanucchi et al., 2019). The ability of HOTTIP to rescue the loss of UMLILO is an example of convergent functional evolution, as they share minimal sequence similarity.

Another group of chromatin-modifying lncRNAs arises from the syntenic estrogen receptor 1 (ESR1) locus. ESR1 is strongly upregulated in cancerous cells undergoing estrogen deprivation. A cluster of ncRNAs, ESR1 locus enhancing and activating non-coding RNAs (Eleanors), are transcribed from introns in a large chromatin cluster within a TAD that contains the ESR1 locus (Tomita et al., 2015). These Eleanors form a chromatin-associated RNA cloud that delineates the TAD and cis-activate transcription. This TAD interacts with another active TAD that contains the apoptotic transcription factor forkhead Box O3 (FOXO3; Abdalla et al., 2019). Knockdown of a promoter-associated Eleanor, pa-Eleanor $(S)$, induced repression of the rest of the Eleanors and the genes within the TAD, including ESR1 (Abdalla et al., 2019). The abundant and highly conserved Eleanor2 increases chromatin accessibility in the ESR1 upstream region by destabilizing nucleosomes, activating ESR1, and is required for the formation of the RNA cloud (Fujita et al., 2020).

\section{Positional Conservation}

Long non-coding RNAs may be expressed from syntenic loci, suggesting a common origin, but may have lost the majority of sequence conservation (Figure 1B). The functions of these lncRNAs are thought to rely primarily on their transcription 
(Diederichs, 2014; Ulitsky, 2016). Thus, the evolutionary signature would be expected to reside outside the transcribed region (Ulitsky, 2016). Indeed, many lncRNAs have a very conserved promoter but little to no conservation in their transcribed region (Guttman et al., 2009). A substantial difficulty in this classification is defining when sequence conservation is entirely lost. As outlined above, several lncRNAs only retain small patches of conservation considered negligible by some authors and meaningful by others.

Examples of this conundrum are dosage compensation lncRNAs in Drosophila melanogaster (Figure 1B). Detailed syntenic analysis of Drosophilid genomes revealed 47 new orthologs, where only 19 had been identified by sequence similarity (Quinn et al., 2016). Importantly, it was shown that the roX RNA itself, only its transcription, is necessary for dosage compensation (Quinn et al., 2016). Furthermore, a distant roX RNA ortholog rescues the loss of roX between two distant species (D. melanogaster and Drosophila busckii) despite almost no sequence conservation outside an eight nucleotide-long conserved patch of microhomology (Quinn et al., 2016).

A more traditional example of positional conservation is the IncRNA antisense to Igf2r RNA non-coding (Airn), required for paternal-specific silencing of imprinted genes in the insulin-like growth factor 2 (Igf2r) cluster (Sleutels et al., 2002). The function of Airn is conserved between human and mouse despite them sharing little conserved sequence (Yotova et al., 2008). The Igf2r silencing function of Airn was shown to be dependent on transcriptional overlap and not on the transcribed RNAs themselves (Latos et al., 2012). However, recent evidence shows that this is only the case for nearby imprinted genes, as the murine Airn lncRNA itself is necessary for the recruitment of chromatin-modifying complexes to distant non-overlapping genes in the cluster (Andergassen et al., 2019).

\section{Structural Conservation}

Structural conservation is potentially the most telling signal of conservation in IncRNAs, yet the most difficult to identify. The basic premise is that structural domains may be preserved despite changes in the sequence, as long as complementary base pairs are maintained.

The non-coding isoform of the steroid receptor RNA activator (SRA), ncSRA, has a four-domain secondary structure with varying levels of sequence conservation (Figure 1C). $n c S R A$ functions as a coactivator of several human hormone receptors by modifying chromatin structure (Novikova et al., 2012). $n c S R A$ associates with CTCF and the DEAD-BOX helicase 5 (DDX5), and this association is necessary for the insulator activity of CTCF in vivo (Yao et al., 2010). The functional RNA structure is conserved in all mammals, while its sequence is not. Furthermore, several of the varying positions in other species show changes predicted to help stabilize its structural elements (Novikova et al., 2012).

Dosage compensation lncRNAs (see next section) show patches of structural conservation of biological importance. The Repeat A (RepA) region of $X$-inactive specific transcript (Xist), essential to the establishment of $\mathrm{X}$ chromosome inactivation, interacts with proteins such as the polycomb repressive complex 2 (PRC2; Zhao et al., 2008), ATRX chromatin remodeler (Sarma et al., 2014), and SHARP repressor protein (McHugh et al., 2015). RepA was experimentally shown to have a complex structure that is preserved despite rapid changes across mammalian evolution, strongly suggesting that this structure is indispensable for Xist function (Liu et al., 2017). IncRNAs involved in dosage compensation in drosophilids, roX1 and roX2, have conserved boxes that correspond precisely with stems that are necessary for binding to the male-specific lethal (MSL) proteins. Domains outside these interaction zones are not conserved and lack structure (Ilik et al., 2013; Quinn et al., 2016).

HOTAIR has also been shown to have a complex secondary structure, with some evidence of conservation in mammals acquired from computational methods (Somarowthu et al., 2015). However, there is some debate as to whether there is enough evidence to suggest that HOTAIR's structure is conserved in mammals (Rivas et al., 2017). Similarly, secondary-structure predictions on Firre indicated that the RRD is a highly structured domain (Nakagawa and Hirano, 2014), consistent with LRs representing potential binding platforms for the specific targeting of proteins to specific genomic regions by lncRNAs.

\section{Functional Convergence: The Case of Dosage Compensation IncRNAs}

The lncRNAs involved in the process of dosage compensation are extraordinary examples of de novo emergence of novel lncRNAs of unrelated evolutionary origins (Figure 1D). A prominent example is the Xist lncRNA, required for dosage compensation in the sex-chromosomes of eutherians (Penny et al., 1996). Random X-chromosome inactivation in females is necessary to balance the transcriptional output to that of males. Xist localizes at the X inactivation center (XIC) and is expressed exclusively from the inactivated X (Xi; Brown et al., 1991). During the onset of X inactivation, Xist accumulates at the XIC (Clemson et al., 1996), and then targets gene-rich regions that are spatially close to its transcription site (Engreitz et al., 2013; Simon et al., 2013), incorporating them into the Xist silencing domain and spreading further to cover the complete future Xi (Engreitz et al., 2013). Xist-mediated inactivation involves the transcriptional silencing of most genes on the $\mathrm{Xi}$, and its compaction and recruitment to the nuclear lamina (Zhao et al., 2008; Hasegawa et al., 2010; Chu et al., 2015; McHugh et al., 2015; Minajigi et al., 2015).

While exonic sequences of Xist are well-conserved among eutherians, there are differences in the exon-intron structure, length, and sequence between species (Nesterova et al., 2001; Elisaphenko et al., 2008). This indicates that either Xist genes present a high adaptation level or that their sequence and structure are not essential (Elisaphenko et al., 2008). Xist is not present in non-eutherian vertebrates, including marsupials, despite common epigenetic features on the $\mathrm{Xi}$, such as loss of active histone marks and exclusion of RNA polymerase II (Chaumeil et al., 2011). Homology of Xist with promoters and exonic sequences of the protein-coding gene ligand of 
numb-protein $\mathrm{x} 3(\operatorname{Ln} \times 3)$ found in marsupials, chicken, and fish suggests that Xist emerged through pseudogenization of Lnx3, possibly by the insertion of tandem repeats from transposable elements (Duret et al., 2006; Elisaphenko et al., 2008).

Interestingly, in marsupials, $\mathrm{X}$-chromosome inactivation is imprinted, tissue-specific, and somewhat incomplete compared to eutherians, and thought to be achieved by female-specific expression of the IncRNA RNA on the silent $X(R s x)$, which is transcribed from and coats the paternal chromosome (Grant et al., 2012). The independent evolution of Xist and Rsx adds to the notion of dosage systems rapidly evolving from ancient silencing mechanisms common to all eukaryotes through the use of lncRNAs (Gendrel and Heard, 2014; Graves, 2016). The discoveries on the regulation of Xist by non-coding elements located at its own and the neighboring TAD and the impact of this $3 \mathrm{D}$ conformation on the regulatory landscape adds another layer of complexity to the mechanisms for dosage compensation (van Bemmel et al., 2019; Galupa et al., 2020).

lncRNAs are also the effectors of dosage compensation in drosophilids, but they differ in both origin and mechanism to those in mammals. Here, the roX1 and roX2 lncRNAs mediate the upregulation of genes on the single male $\mathrm{X}$ chromosome to equalize expression of the two $\mathrm{X}$ chromosomes in females. roX1 and roX2 associate to the MSL proteins, forming the MSL complex that localizes to numerous specific sites along the male X (Franke and Baker, 1999), mediating histone acetylation and increasing transcription. The MSL complex does not alter the global architecture of the $\mathrm{X}$ chromosome, but it does spread via spatial proximity from high-affinity sites - enriched at TAD boundaries - to other regions (Ramírez et al., 2015). Contrary to Xist, whose activity is limited to the chromosome from which it is expressed (Wutz and Jaenisch, 2000), roX transgenes target the $\mathrm{X}$ chromosome in trans and rescue roX1 and roX2 mutant males (Meller and Rattner, 2002).

The independent origin of Xist in mammals, Rs $x$ in marsupials, and roX 1 and roX2 in flies suggests that lncRNAs may be one of the fastest mechanisms to evolve novel epigenetic controls. As these lncRNAs participate in dosage compensation but have emerged independently in several lineages, they are extraordinarily difficult to identify as functionally convergent. Additional examples of functionally equivalent lncRNAs with no evolutionary relationship may likely have gone undetected.

\section{DISCUSSION}

Distinctly, lncRNAs have emerged as an additional layer of complexity involved in shaping the three-dimensional organization of the genome by interacting and modifying the structure of chromatin. Several lncRNAs affect chromatin conformation and display a combination of conservation signals that may be difficult to identify solely by looking at traditional genomic conservation metrics (summarized in Table 1). These signatures could prove useful to identify and prioritize lncRNA

TABLE 1 | Characterized long non-coding RNAs (IncRNAs) that are involved in nuclear genome topology.

\begin{tabular}{|c|c|c|c|c|c|c|}
\hline IncRNA & Function & $\begin{array}{l}\text { Mode of } \\
\text { action }\end{array}$ & Interacting proteins & $\begin{array}{l}\text { Association with chromatin } \\
\text { topology }\end{array}$ & Conservation & References \\
\hline Xist & $\begin{array}{l}\mathrm{X} \text { chromosome } \\
\text { inactivation in mammals }\end{array}$ & In cis & $\begin{array}{l}\text { PRC1, PRC2, } \\
\text { HNRNPU, RBM15, } \\
\text { SHARP, WTAP, } \\
\text { HNRNPK, LBR, and } \\
\text { many others }\end{array}$ & $\begin{array}{l}\text { The organization of the XIC into two } \\
\text { topologically associating domains } \\
\text { (TADs) ensures the proper } \\
\text { interaction of Xist and its antisense } \\
\text { IncRNA Tsix with regulatory } \\
\text { elements } \\
\text { During X inactivation, Xist spreads } \\
\text { along the chromosome exploiting } \\
\text { the three-dimensional (3D) } \\
\text { organization, resulting in } \\
\text { compaction and recruitment to the } \\
\text { nuclear lamina }\end{array}$ & $\begin{array}{l}\text { Present only in } \\
\text { eutherian mammals. } \\
\text { Presence of common } \\
\text { core exonic } \\
\text { sequences, despite } \\
\text { species-specific } \\
\text { unique sequences, } \\
\text { and variation in length } \\
\text { and gene structure }\end{array}$ & $\begin{array}{l}\text { Nesterova et al., } \\
\text { 2001; Plath et al., } \\
\text { 2003; Elisaphenko } \\
\text { et al., 2008; Zhao } \\
\text { et al., 2008; } \\
\text { Hasegawa et al., } \\
\text { 2010; Engreitz et al., } \\
\text { 2013; Chu et al., } \\
\text { 2015; McHugh et al., } \\
\text { 2015; Minajigi et al., } \\
\text { 2015; Moindrot et al., } \\
\text { 2015; Chen et al., } \\
\text { 2016; Pintacuda et al., } \\
\text { 2017; van Bemmel } \\
\text { et al., 2019; Galupa } \\
\text { et al., } 2020\end{array}$ \\
\hline HOTTIP & $\begin{array}{l}\text { Gene control of HOXA } \\
\text { locus for distal identity }\end{array}$ & In cis & WDR5/MLL and CTCF & $\begin{array}{l}\text { A chromatin loop gets HOTTIP into } \\
\text { spatial proximity to HOXA genes. } \\
\text { Associates with CTCF to define } \\
\text { functional TADs at HOXA cluster }\end{array}$ & $\begin{array}{l}\text { Portions conserved in } \\
\text { mammals and avians }\end{array}$ & $\begin{array}{l}\text { Wang et al., 2011, } \\
2018\end{array}$ \\
\hline Airn & $\begin{array}{l}\text { Its transcription } \\
\text { prevents } \\
\text { overexpression of lgfr2 } \\
\text { locus in a paternal- } \\
\text { specific matter }\end{array}$ & In cis & EHMT2 & $\begin{array}{l}\text { Forms an RNA cloud, creating a } \\
\text { repressive domain }\end{array}$ & $\begin{array}{l}\text { Tandem direct } \\
\text { repeats at the CpG } \\
\text { island at } 5 \text { ' end are } \\
\text { conserved in human } \\
\text { and mouse at an } \\
\text { organizational level } \\
\text { but not by sequence }\end{array}$ & $\begin{array}{l}\text { Lyle et al., 2000; Seidl } \\
\text { et al., 2006; Nagano } \\
\text { et al., 2008; Latos } \\
\text { et al., 2009, 2012; } \\
\text { Koerner et al., 2012; } \\
\text { Santoro et al., } 2013\end{array}$ \\
\hline
\end{tabular}


TABLE 1 | Continued

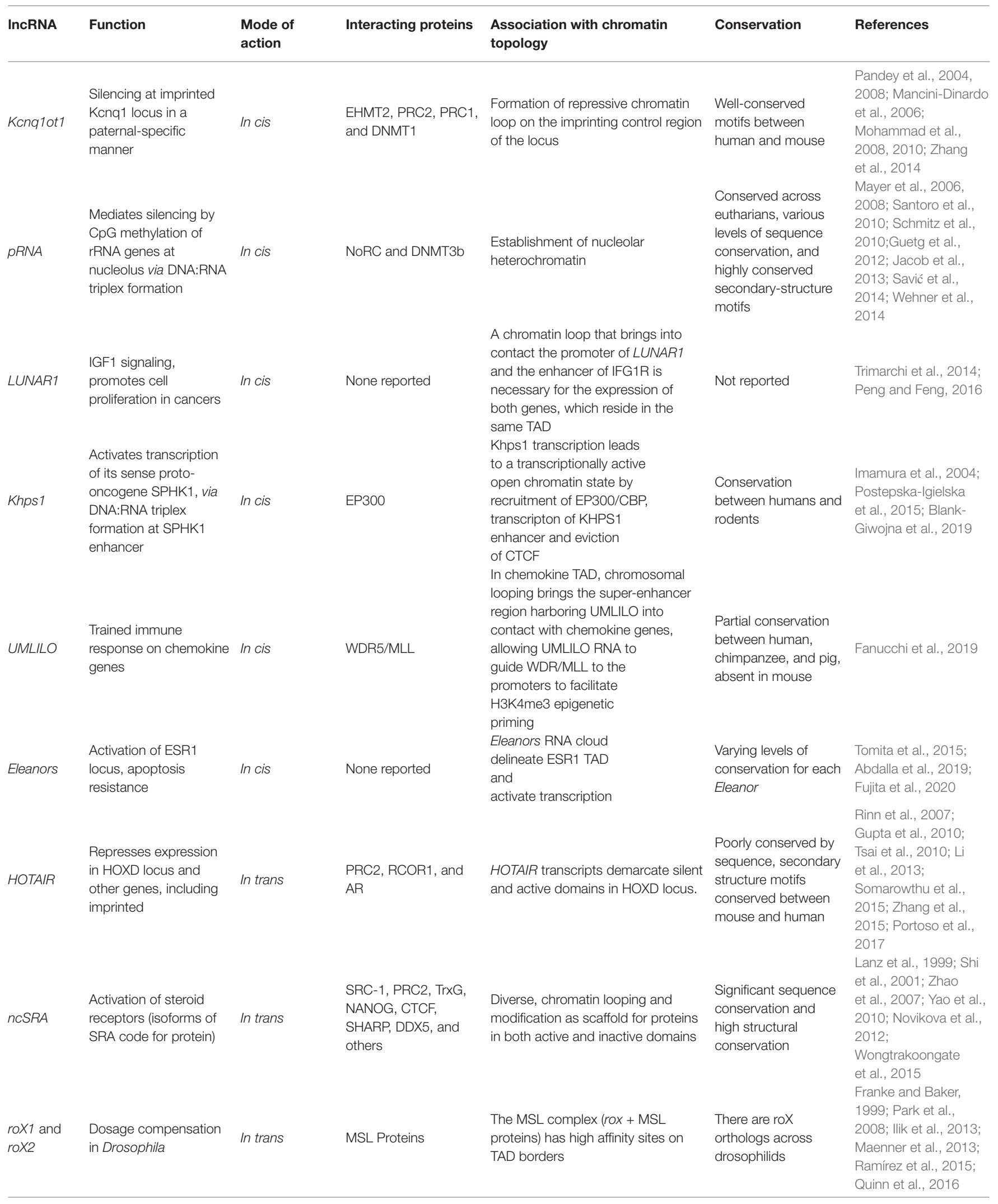

(Continued) 
TABLE 1 | Continued

\begin{tabular}{|c|c|c|c|c|c|c|}
\hline IncRNA & Function & $\begin{array}{l}\text { Mode of } \\
\text { action }\end{array}$ & Interacting proteins & $\begin{array}{l}\text { Association with chromatin } \\
\text { topology }\end{array}$ & Conservation & References \\
\hline$I P W$ & $\begin{array}{l}\text { Repression of } \\
\text { maternally expressed } \\
\text { genes. Possibly } \\
\text { implicated in Prader- } \\
\text { Willi syndrome }\end{array}$ & In trans & EHMT2 & $\begin{array}{l}\text { Allele-specific formation of } \\
\text { heterochromatin at DLK1-DIO3 } \\
\text { region. }\end{array}$ & $\begin{array}{l}\text { Poorly conserved by } \\
\text { sequence between } \\
\text { human and mouse }\end{array}$ & $\begin{array}{l}\text { Wevrick et al., 1994; } \\
\text { Wevrick and Francke, } \\
\text { 1997; Stelzer et al., } \\
2014\end{array}$ \\
\hline Firre & $\begin{array}{l}\text { Role in adipogenesis, } \\
\text { nuclear architecture, } \\
\text { inflammatory response } \\
\text { (in vitro), and } \\
\text { hematopoiesis (in vivo) }\end{array}$ & $\begin{array}{l}\text { In trans, but } \\
\text { occupies } \\
\text { domain in cis }\end{array}$ & HNRNPU & $\begin{array}{l}\text { Firre acts as a scaffold for the } \\
\text { formation of an inter-chromosomal } \\
\text { structure. Locates at border of TAD } \\
\text { in a CTCF binding region. Required } \\
\text { for super loop formation of inactive } \\
X\end{array}$ & $\begin{array}{l}\text { Conservation across } \\
\text { mammals, high } \\
\text { convergence of } \\
\text { repeating domain in } \\
\text { primates. Local } \\
\text { Repeats are conserved } \\
\text { between species of } \\
\text { the same order }\end{array}$ & $\begin{array}{l}\text { Hacisuleyman et al., } \\
\text { 2014, 2016; Yang } \\
\text { et al., 2015; Lu et al., } \\
\text { 2017; Barutcu et al., } \\
\text { 2018; Lewandowski } \\
\text { et al., } 2019\end{array}$ \\
\hline TERRA & $\begin{array}{l}\text { Implicated in telomeric } \\
\text { and subtelomeric } \\
\text { heterochromatin } \\
\text { formation, stability and } \\
\text { maintenance }\end{array}$ & $\begin{array}{l}\text { In cis (to } \\
\text { telomeres) and } \\
\text { in trans }\end{array}$ & $\begin{array}{l}\text { Shelterin components } \\
\text { (TERF1 and TERF2), } \\
\text { ORC1, CBX5 NoRC, } \\
\text { ATRX, POT1, and } \\
\text { others }\end{array}$ & $\begin{array}{l}\text { TERRA transcription depends on } \\
\text { chromosome looping }\end{array}$ & $\begin{array}{l}\text { Telomere transcription } \\
\text { is conserved across } \\
\text { vertebrates and } \\
\text { Saccharomyces } \\
\text { cerevisiae }\end{array}$ & $\begin{array}{l}\text { Azzalin et al., 2007; } \\
\text { Luke et al., 2008; } \\
\text { Schoeftner and } \\
\text { Blasco, 2008; Deng } \\
\text { et al., 2009; } \\
\text { Postepska-lgielska } \\
\text { et al., 2013; Beishline } \\
\text { et al., } 2017\end{array}$ \\
\hline
\end{tabular}

candidates for experimental functional characterization. Sequence conservation can be identified using traditional computational sequence comparison methods. Recent examples have shown that conserved sequence stretches can be much shorter in lncRNAs than in protein-coding sequences, highlighting the need to look for tiny stretches of sequence conservation (microhomology; Quinn et al., 2016). Positional conservation of $\operatorname{lncRNAs}$ can be identified using multiple genome alignments complemented with transcriptomic data that support the existence of non-coding transcripts in multiple taxa. The detection of splice site conservation uses a similar approach but focuses on identifying splice sites via modeling or direct RNA-seq evidence, followed by comparison across taxa (Nitsche et al., 2015). In the case of structural conservation, covariation signatures in multiple sequence alignments may indicate the conservation of a structure (Nawrocki et al., 2009; Gruber et al., 2010; Will et al., 2012). One of the most significant limitations is the difficult problem of distinguishing covariation from sequence conservation. Thus, these methods can better identify conserved structures in highly varying sequences in diverse and multiple taxa (Rivas et al., 2017, 2020).

In the context of studying novel lncRNAs, its unique conservation signatures, albeit more difficult to detect, are

\section{REFERENCES}

Abdalla, M. O. A., Yamamoto, T., Maehara, K., Nogami, J., Ohkawa, Y., Miura, H., et al. (2019). The Eleanor ncRNAs activate the topological domain of the ESR1 locus to balance against apoptosis. Nat. Commun. 10:3778. doi: 10.1038/ s41467-019-11378-4

Andergassen, D., Muckenhuber, M., Bammer, P. C., Kulinski, T. M., Theussl, H. -C., Shimizu, T., et al. (2019). The Airn lncRNA does not require any DNA elements within its locus to silence distant imprinted genes. PLoS Genet. 15:e1008268. doi: 10.1371/journal.pgen.1008268 excellent ways to identify potentially functional lncRNA candidates and give a first insight on their possible mechanisms of action. They can also help guide the search for homologous mechanisms in other species. Complementing in silico studies with experimental approaches in the context of spatiotemporal gene expression programs is crucial to further assess the impact of these ncRNAs on modulating genome architecture, including their specific contribution to the complexity and evolution of animal gene regulation.

\section{AUTHOR CONTRIBUTIONS}

All authors participated in writing and reviewing the manuscript and approved the final version for publication.

\section{FUNDING}

AR-C was funded by the Consejo Nacional de Ciencia y Tecnología (CONACYT) M.Sc. fellowship. KO and SF-V were funded by the Newton Advanced Fellowship (No. NAFI R1\180303) awarded to SF-V. 
Battistelli, C., Sabarese, G., Santangelo, L., Montaldo, C., Gonzalez, F. J., Tripodi, M., et al. (2019). The IncRNA HOTAIR transcription is controlled by HNF4 $\alpha$-induced chromatin topology modulation. Cell Death Differ. 26, 890-901. doi: 10.1038/s41418-018-0170-Z

Beishline, K., Vladimirova, O., Tutton, S., Wang, Z., Deng, Z., and Lieberman, P. M. (2017). CTCF driven TERRA transcription facilitates completion of telomere DNA replication. Nat. Commun. 8:2114. doi: 10.1038/s41467-017-02212-w

Bell, J. C., Jukam, D., Teran, N. A., Risca, V. I., Smith, O. K., Johnson, W. L., et al. (2018). Chromatin-associated RNA sequencing (ChAR-seq) maps genome-wide RNA-to-DNA contacts. eLife 7:e27024. doi: 10.7554/eLife.27024

Blank-Giwojna, A., Postepska-Igielska, A., and Grummt, I. (2019). IncRNA KHPS1 activates a poised enhancer by triplex-dependent recruitment of epigenomic regulators. Cell Rep. 26:2904.e4-2915.e4. doi: 10.1016/j. celrep.2019.02.059

Bonetti, A., Agostini, F., Suzuki, A. M., Hashimoto, K., Pascarella, G., Gimenez, J., et al. (2020). RADICL-seq identifies general and cell type-specific principles of genome-wide RNA-chromatin interactions. Nat. Commun. 11:1018. doi: 10.1038/s41467-020-14337-6

Brown, C. J., Ballabio, A., Rupert, J. L., Lafreniere, R. G., Grompe, M., Tonlorenzi, R., et al. (1991). A gene from the region of the human X inactivation centre is expressed exclusively from the inactive $\mathrm{X}$ chromosome. Nature 349, 38-44. doi: 10.1038/349038a0

Chaumeil, J., Waters, P. D., Koina, E., Gilbert, C., Robinson, T. J., and Graves, J. A. M. (2011). Evolution from XIST-independent to XIST-controlled X-chromosome inactivation: epigenetic modifications in distantly related mammals. PLoS One 6:e19040. doi: 10.1371/journal.pone.0019040

Chen, C. -K., Blanco, M., Jackson, C., Aznauryan, E., Ollikainen, N., Surka, C., et al. (2016). Xist recruits the $\mathrm{X}$ chromosome to the nuclear lamina to enable chromosome-wide silencing. Science 354, 468-472. doi: 10.1126/science.aae0047

Chu, C., Zhang, Q. C., da Rocha, S. T., Flynn, R. A., Bharadwaj, M., Calabrese, J. M., et al. (2015). Systematic discovery of Xist RNA binding proteins. Cell 161, 404-416. doi: 10.1016/j.cell.2015.03.025

Clark, M. B., Amaral, P. P., Schlesinger, F. J., Dinger, M. E., Taft, R. J., Rinn, J. L., et al. (2011). The reality of pervasive transcription. PLoS Biol. 9:e1000625. doi: 10.1371/journal.pbio.1000625

Clemson, C. M., McNeil, J. A., Willard, H. F., and Lawrence, J. B. (1996). XIST RNA paints the inactive $\mathrm{X}$ chromosome at interphase: evidence for a novel RNA involved in nuclear/chromosome structure. J. Cell Biol. 132, 259-275. doi: $10.1083 /$ jcb.132.3.259

Delás, M. J., Joaquina Delás, M., and Hannon, G. J. (2017). IncRNAs in development and disease: from functions to mechanisms. Open Biol. 7:170121. doi: $10.1098 /$ rsob.170121

Deng, Z., Norseen, J., Wiedmer, A., Riethman, H., and Lieberman, P. M. (2009). TERRA RNA binding to TRF2 facilitates heterochromatin formation and ORC recruitment at telomeres. Mol. Cell 35, 403-413. doi: 10.1016/j. molcel.2009.06.025

Derrien, T., Johnson, R., Bussotti, G., Tanzer, A., Djebali, S., Tilgner, H., et al. (2012). The GENCODE v7 catalog of human long noncoding RNAs: analysis of their gene structure, evolution, and expression. Genome Res. 22, 1775-1789. doi: $10.1101 /$ gr.132159.111

Diederichs, S. (2014). The four dimensions of noncoding RNA conservation. Trends Genet. 30, 121-123. doi: 10.1016/j.tig.2014.01.004

Dixon, J. R., Jung, I., Selvaraj, S., Shen, Y., Antosiewicz-Bourget, J. E., Lee, A. Y., et al. (2015). Chromatin architecture reorganization during stem cell differentiation. Nature 518, 331-336. doi: 10.1038/nature14222

Dixon, J. R., Selvaraj, S., Yue, F., Kim, A., Li, Y., Shen, Y., et al. (2012). Topological domains in mammalian genomes identified by analysis of chromatin interactions. Nature 485, 376-380. doi: 10.1038/nature11082

Duret, L., Chureau, C., Samain, S., Weissenbach, J., and Avner, P. (2006). The Xist RNA gene evolved in eutherians by pseudogenization of a proteincoding gene. Science 312, 1653-1655. doi: 10.1126/science.1126316

Eißmann, M., Gutschner, T., Hämmerle, M., Günther, S., Caudron-Herger, M., Groß, M., et al. (2012). Loss of the abundant nuclear non-coding RNA MALAT1 is compatible with life and development. RNA Biol. 9, 1076-1087. doi: $10.4161 /$ rna.21089

Elisaphenko, E. A., Kolesnikov, N. N., Shevchenko, A. I., Rogozin, I. B., Nesterova, T. B., Brockdorff, N., et al. (2008). A dual origin of the Xist gene from a protein-coding gene and a set of transposable elements. PLoS One 3:6. doi: 10.1371/journal.pone.0002521
Engreitz, J. M., Pandya-Jones, A., McDonel, P., Shishkin, A., Sirokman, K., Surka, C., et al. (2013). The Xist lncRNA exploits three-dimensional genome architecture to spread across the X chromosome. Science 341:1237973. doi: 10.1126/science. 1237973

Fanucchi, S., Fok, E. T., Dalla, E., Shibayama, Y., Börner, K., Chang, E. Y., et al. (2019). Immune genes are primed for robust transcription by proximal long noncoding RNAs located in nuclear compartments. Nat. Genet. 51, 138-150. doi: 10.1038/s41588-018-0298-2

Fortin, J. -P., and Hansen, K. D. (2015). Reconstructing A/B compartments as revealed by $\mathrm{Hi}-\mathrm{C}$ using long-range correlations in epigenetic data. Genome Biol. 16:180. doi: 10.1186/s13059-015-0741-y

Franke, A., and Baker, B. S. (1999). The rox1 and rox2 RNAs are essential components of the compensasome, which mediates dosage compensation in Drosophila. Mol. Cell 4, 117-122. doi: 10.1016/S1097-2765(00)80193-8

Fujita, R., Yamamoto, T., Arimura, Y., Fujiwara, S., Tachiwana, H., Ichikawa, Y., et al. (2020). Nucleosome destabilization by nuclear non-coding RNAs. Commun. Biol. 3:60. doi: 10.1038/s42003-020-0784-9

Furlong, E. E. M., and Levine, M. (2018). Developmental enhancers and chromosome topology. Science 361, 1341-1345. doi: 10.1126/science.aau0320

Gaiti, F., Calcino, A. D., Tanurdžić, M., and Degnan, B. M. (2017). Origin and evolution of the metazoan non-coding regulatory genome. Dev. Biol. 427, 193-202. doi: 10.1016/j.ydbio.2016.11.013

Galupa, R., Nora, E. P., Worsley-Hunt, R., Picard, C., Gard, C., van Bemmel, J. G., et al. (2020). A conserved noncoding locus regulates random monoallelic Xist expression across a topological boundary. Mol. Cell 77, 352.e8-367.e8. doi: $10.1016 /$ j.molcel.2019.10.030

Gavrilov, A. A., Zharikova, A. A., Galitsyna, A. A., Luzhin, A. V., Rubanova, N. M., Golov, A. K., et al. (2020). Studying RNA-DNA interactome by Red-C identifies noncoding RNAs associated with various chromatin types and reveals transcription dynamics. Nucleic Acids Res. 48, 6699-6714. doi: 10.1093/nar/gkaa457

Gendrel, A. -V., and Heard, E. (2014). Noncoding RNAs and epigenetic mechanisms during X-chromosome inactivation. Annu. Rev. Cell Dev. Biol. 30, 561-580. doi: 10.1146/annurev-cellbio-101512-122415

Grant, J., Mahadevaiah, S. K., Khil, P., Sangrithi, M. N., Royo, H., Duckworth, J., et al. (2012). Rsx is a metatherian RNA with Xist-like properties in X-chromosome inactivation. Nature 487, 254-258. doi: 10.1038/nature11171

Graves, J. A. M. (2016). Evolution of vertebrate sex chromosomes and dosage compensation. Nat. Rev. Genet. 17, 33-46. doi: 10.1038/nrg.2015.2

Gruber, A. R., Findeiß, S., Washietl, S., Hofacker, I. L., and Stadler, P. F. (2010). RNAz 2.0: improved noncoding RNA detection. Pac. Symp. Biocomput. 2010, 69-79. doi: 10.1142/9789814295291_0009

Guetg, C., Scheifele, F., Rosenthal, F., Hottiger, M. O., and Santoro, R. (2012). Inheritance of silent rDNA chromatin is mediated by PARP1 via noncoding RNA. Mol. Cell 45, 790-800. doi: 10.1016/j.molcel.2012.01.024

Gupta, R. A., Shah, N., Wang, K. C., Kim, J., Horlings, H. M., Wong, D. J., et al. (2010). Long non-coding RNA HOTAIR reprograms chromatin state to promote cancer metastasis. Nature 464, 1071-1076. doi: 10.1038/nature08975

Gutschner, T., Hämmerle, M., and Diederichs, S. (2013). MALAT1--a paradigm for long noncoding RNA function in cancer. J. Mol. Med. 91, 791-801. doi: 10.1007/s00109-013-1028-y

Guttman, M., Amit, I., Garber, M., French, C., Lin, M. F., Feldser, D., et al. (2009). Chromatin signature reveals over a thousand highly conserved large non-coding RNAs in mammals. Nature 458, 223-227. doi: 10.1038/nature07672

Guttman, M., Donaghey, J., Carey, B. W., Garber, M., Grenier, J. K., Munson, G., et al. (2011). lincRNAs act in the circuitry controlling pluripotency and differentiation. Nature 477, 295-300. doi: 10.1038/nature10398

Hacisuleyman, E., Goff, L. A., Trapnell, C., Williams, A., Henao-Mejia, J., Sun, L., et al. (2014). Topological organization of multichromosomal regions by the long intergenic noncoding RNA Firre. Nat. Struct. Mol. Biol. 21, 198-206. doi: 10.1038/nsmb.2764

Hacisuleyman, E., Shukla, C. J., Weiner, C. L., and Rinn, J. L. (2016). Function and evolution of local repeats in the Firre locus. Nat. Commun. 7:11021. doi: 10.1038/ncomms11021

Hasegawa, Y., Brockdorff, N., Kawano, S., Tsutui, K., Tsutui, K., and Nakagawa, S. (2010). The matrix protein hnRNP U is required for chromosomal localization of Xist RNA. Dev. Cell 19, 469-476. doi: 10.1016/j.devcel.2010.08.006

He, S., Liu, S., and Zhu, H. (2011). The sequence, structure and evolutionary features of HOTAIR in mammals. BMC Evol. Biol. 11:102. doi: 10.1186/1471-2148-11-102 
Hezroni, H., Koppstein, D., Schwartz, M. G., Avrutin, A., Bartel, D. P., and Ulitsky, I. (2015). Principles of long noncoding RNA evolution derived from direct comparison of transcriptomes in 17 species. Cell Rep. 11, 1110-1122. doi: 10.1016/j.celrep.2015.04.023

Hutchinson, J. N., Ensminger, A. W., Clemson, C. M., Lynch, C. R., Lawrence, J. B., and Chess, A. (2007). A screen for nuclear transcripts identifies two linked noncoding RNAs associated with $\mathrm{SC}_{35}$ splicing domains. BMC Genom. 8:39. doi: 10.1186/1471-2164-8-39

Ibrahim, D. M., and Mundlos, S. (2020). The role of 3D chromatin domains in gene regulation: a multi-facetted view on genome organization. Curr. Opin. Genet. Dev. 61, 1-8. doi: 10.1016/j.gde.2020.02.015

Ilik, I. A., Quinn, J. J., Georgiev, P., Tavares-Cadete, F., Maticzka, D., Toscano, S., et al. (2013). Tandem stem-loops in roX RNAs act together to mediate $\mathrm{X}$ chromosome dosage compensation in Drosophila. Mol. Cell 51, 156-173. doi: 10.1016/j.molcel.2013.07.001

Imamura, T., Yamamoto, S., Ohgane, J., Hattori, N., Tanaka, S., and Shiota, K. (2004). Non-coding RNA directed DNA demethylation of Sphk1 CpG island. Biochem. Biophys. Res. Commun. 322, 593-600. doi: 10.1016/j.bbrc.2004.07.159

Jacob, M. D., Audas, T. E., Uniacke, J., Trinkle-Mulcahy, L., and Lee, S. (2013). Environmental cues induce a long noncoding RNA-dependent remodeling of the nucleolus. Mol. Biol. Cell 24, 2943-2953. doi: 10.1091/mbc.e13-04-0223

Kapusta, A., and Feschotte, C. (2014). Volatile evolution of long noncoding RNA repertoires: mechanisms and biological implications. Trends Genet. 30, 439-452. doi: 10.1016/J.TIG.2014.08.004

Koerner, M. V., Pauler, F. M., Hudson, Q. J., Santoro, F., Sawicka, A., Guenzl, P. M., et al. (2012). A downstream CpG island controls transcript initiation and elongation and the methylation state of the imprinted Airn macro ncRNA promoter. PLoS Genet. 8:e1002540. doi: 10.1371/journal.pgen.1002540

Lanz, R. B., McKenna, N. J., Onate, S. A., Albrecht, U., Wong, J., Tsai, S. Y., et al. (1999). A steroid receptor coactivator, SRA, functions as an RNA and is present in an SRC-1 complex. Cell 97, 17-27. doi: 10.1016/ s0092-8674(00)80711-4

Latos, P. A., Pauler, F. M., Koerner, M. V., Şenergin, H. B., Hudson, Q. J., Stocsits, R. R., et al. (2012). Airn transcriptional overlap, but not its IncRNA products, induces imprinted Igf2r silencing. Science 338, 1469-1472. doi: $10.1126 /$ science. 1228110

Latos, P. A., Stricker, S. H., Steenpass, L., Pauler, F. M., Huang, R., Senergin, B. H., et al. (2009). An in vitro ES cell imprinting model shows that imprinted expression of the Igf2r gene arises from an allele-specific expression bias. Development 136, 437-448. doi: 10.1242/dev.032060

Lewandowski, J. P., Lee, J. C., Hwang, T., Sunwoo, H., Goldstein, J. M., Groff, A. F, et al. (2019). The Firre locus produces a trans-acting RNA molecule that functions in hematopoiesis. Nat. Commun. 10:5137. doi: 10.1038/s41467-019-12970-4

Li, L., Liu, B., Wapinski, O. L., Tsai, M. -C., Qu, K., Zhang, J., et al. (2013). Targeted disruption of Hotair leads to homeotic transformation and gene derepression. Cell Rep. 5, 3-12. doi: 10.1016/j.celrep.2013.09.003

Li, X., Zhou, B., Chen, L., Gou, L. T., Li, H., and Fu, X. D. (2017). GRID-seq reveals the global RNA-chromatin interactome. Nat. Biotechnol. 35, 940-950. doi: $10.1038 /$ nbt. 3968

Lieberman-Aiden, E., van Berkum, N. L., Williams, L., Imakaev, M., Ragoczy, T., Telling, A., et al. (2009). Comprehensive mapping of long-range interactions reveals folding principles of the human genome. Science 326, 289-293. doi: 10.1126/SCIENCE.1181369

Lin, N., Chang, K. -Y., Li, Z., Gates, K., Rana, Z. A., Dang, J., et al. (2014). An evolutionarily conserved long noncoding RNA TUNA controls pluripotency and neural lineage commitment. Mol. Cell 53, 1005-1019. doi: 10.1016/j. molcel.2014.01.021

Lin, R., Maeda, S., Liu, C., Karin, M., and Edgington, T. S. (2007). A large noncoding RNA is a marker for murine hepatocellular carcinomas and a spectrum of human carcinomas. Oncogene 26, 851-858. doi: 10.1038/sj.onc.1209846

Lindsay, M. A., Griffiths-Jones, S., Clark, M. B., Choudhary, A., Smith, M. A., Taft, R. J., et al. (2013). The dark matter rises: the expanding world of regulatory RNAs. Essays Biochem. 54, 1-16. doi: 10.1042/bse0540001

Liu, F., Somarowthu, S., and Pyle, A. M. (2017). Visualizing the secondary and tertiary architectural domains of lncRNA RepA. Nat. Chem. Biol. 13, 282-289. doi: 10.1038/nchembio.2272

Lu, Y., Liu, X., Xie, M., Liu, M., Ye, M., Li, M., et al. (2017). The NF-kBresponsive long noncoding RNA FIRRE regulates posttranscriptional regulation of inflammatory gene expression through interacting with hnRNPU. J. Immunol. 199, 3571-3582. doi: 10.4049/jimmunol.1700091

Luke, B., Panza, A., Redon, S., Iglesias, N., Li, Z., and Lingner, J. (2008). The Ratlp 5' to $3^{\prime}$ exonuclease degrades telomeric repeat-containing RNA and promotes telomere elongation in Saccharomyces cerevisiae. Mol. Cell 32, 465-477. doi: 10.1016/j.molcel.2008.10.019

Lyle, R., Watanabe, D., te Vruchte, D., Lerchner, W., Smrzka, O. W., Wutz, A., et al. (2000). The imprinted antisense RNA at the Igf2r locus overlaps but does not imprint Mas1. Nat. Genet. 25, 19-21. doi: 10.1038/75546

Maenner, S., Müller, M., Fröhlich, J., Langer, D., and Becker, P. B. (2013). ATP-dependent roX RNA remodeling by the helicase maleless enables specific association of MSL proteins. Mol. Cell 51, 174-184. doi: 10.1016/j. molcel.2013.06.011

Mancini-Dinardo, D., Steele, S. J. S., Levorse, J. M., Ingram, R. S., and Tilghman, S. M. (2006). Elongation of the Kcnqlot1 transcript is required for genomic imprinting of neighboring genes. Genes Dev. 20, 1268-1282. doi: 10.1101/gad.1416906

Mao, Y. S., Sunwoo, H., Zhang, B., and Spector, D. L. (2011). Direct visualization of the co-transcriptional assembly of a nuclear body by noncoding RNAs. Nat. Cell Biol. 13, 95-101. doi: 10.1038/ncb2140

Marchese, F. P., and Huarte, M. (2014). Long non-coding RNAs and chromatin modifiers: their place in the epigenetic code. Epigenetics 9, 21-26. doi: 10.4161/epi.27472

Marín-Béjar, O., Mas, A. M., González, J., Martinez, D., Athie, A., Morales, X., et al. (2017). The human IncRNA LINC-PINT inhibits tumor cell invasion through a highly conserved sequence element. Genome Biol. 18:202. doi: 10.1186/s13059-017-1331-y

Marques, A. C., and Ponting, C. P. (2009). Catalogues of mammalian long noncoding RNAs: modest conservation and incompleteness. Genome Biol. 10:R124. doi: 10.1186/gb-2009-10-11-r124

Mayer, C., Neubert, M., and Grummt, I. (2008). The structure of NoRC-associated RNA is crucial for targeting the chromatin remodelling complex NoRC to the nucleolus. EMBO Rep. 9, 774-780. doi: 10.1038/embor.2008.109

Mayer, C., Schmitz, K. -M., Li, J., Grummt, I., and Santoro, R. (2006). Intergenic transcripts regulate the epigenetic state of rRNA genes. Mol. Cell 22, 351-361. doi: 10.1016/j.molcel.2006.03.028

McHugh, C. A., Chen, C. -K., Chow, A., Surka, C. F., Tran, C., McDonel, P., et al. (2015). The Xist IncRNA interacts directly with SHARP to silence transcription through HDAC3. Nature 521, 232-236. doi: 10.1038/nature 14443

Meller, V. H., and Rattner, B. P. (2002). The roX genes encode redundant male-specific lethal transcripts required for targeting of the MSL complex. EMBO J. 21, 1084-1091. doi: 10.1093/emboj/21.5.1084

Mercer, T. R., Dinger, M. E., and Mattick, J. S. (2009). Long non-coding RNAs: insights into functions. Nat. Rev. Genet. 10, 155-159. doi: 10.1038/nrg2521

Minajigi, A., Froberg, J. E., Wei, C., Sunwoo, H., Kesner, B., Colognori, D., et al. (2015). Chromosomes. A comprehensive Xist interactome reveals cohesin repulsion and an RNA-directed chromosome conformation. Science 349:aab2276. doi: 10.1126/science.aab2276

Mohammad, F., Mondal, T., Guseva, N., Pandey, G. K., and Kanduri, C. (2010). Kcnq1ot1 noncoding RNA mediates transcriptional gene silencing by interacting with Dnmt1. Development 137, 2493-2499. doi: 10.1242/dev.048181

Mohammad, F., Pandey, R. R., Nagano, T., Chakalova, L., Mondal, T., Fraser, P., et al. (2008). Kcnq1ot1/Lit1 noncoding RNA mediates transcriptional silencing by targeting to the perinucleolar region. Mol. Cell. Biol. 28, 3713-3728. doi: $10.1128 / \mathrm{mcb} .02263-07$

Moindrot, B., Cerase, A., Coker, H., Masui, O., Grijzenhout, A., Pintacuda, G., et al. (2015). A pooled shRNA screen identifies Rbm15, Spen, and Wtap as factors required for Xist RNA-mediated silencing. Cell Rep. 12, 562-572. doi: 10.1016/j.celrep.2015.06.053

Nagano, T., Mitchell, J. A., Sanz, L. A., Pauler, F. M., Ferguson-Smith, A. C., Feil, R., et al. (2008). The air noncoding RNA epigenetically silences transcription by targeting G9a to chromatin. Science 322, 1717-1720. doi: $10.1126 /$ science. 1163802

Nakagawa, S., and Hirano, T. (2014). Gathering around Firre. Nat. Struct. Mol. Biol. 21, 207-208. doi: 10.1038/nsmb.2782

Nakagawa, S., Ip, J. Y., Shioi, G., Tripathi, V., Zong, X., Hirose, T., et al. (2012). Malat1 is not an essential component of nuclear speckles in mice. RNA 18, 1487-1499. doi: 10.1261/rna.033217.112 
Narendra, V., Rocha, P. P., An, D., Raviram, R., Skok, J. A., Mazzoni, E. O., et al. (2015). CTCF establishes discrete functional chromatin domains at the Hox clusters during differentiation. Science 347, 1017-1021. doi: 10.1126/ science. 1262088

Nawrocki, E. P., Kolbe, D. L., and Eddy, S. R. (2009). Infernal 1.0: inference of RNA alignments. Bioinformatics 25, 1335-1337. doi: 10.1093/bioinformatics/ btp326

Necsulea, A., Soumillon, M., Warnefors, M., Liechti, A., Daish, T., Zeller, U., et al. (2014). The evolution of lncRNA repertoires and expression patterns in tetrapods. Nature 505, 635-640. doi: 10.1038/nature12943

Nesterova, T. B., Slobodyanyuk, S. Y., Elisaphenko, E. A., Shevchenko, A. I., Johnston, C., Pavlova, M. E., et al. (2001). Characterization of the genomic Xist locus in rodents reveals conservation of overall gene structure and tandem repeats but rapid evolution of unique sequence. Genome Res. 11, 833-849. doi: 10.1101/gr.174901

Nitsche, A., Rose, D., Fasold, M., Reiche, K., and Stadler, P. F. (2015). Comparison of splice sites reveals that long noncoding RNAs are evolutionarily well conserved. RNA 21, 801-812. doi: 10.1261/rna.046342.114

Novikova, I. V., Hennelly, S. P., and Sanbonmatsu, K. Y. (2012). Structural architecture of the human long non-coding RNA, steroid receptor RNA activator. Nucleic Acids Res. 40, 5034-5051. doi: 10.1093/nar/gks071

Pandey, R. R., Ceribelli, M., Singh, P. B., Ericsson, J., Mantovani, R., and Kanduri, C. (2004). NF-Y regulates the antisense promoter, bidirectional silencing, and differential epigenetic marks of the Kcnq1 imprinting control region. J. Biol. Chem. 279, 52685-52693. doi: 10.1074/jbc.M408084200

Pandey, R. R., Mondal, T., Mohammad, F., Enroth, S., Redrup, L., Komorowski, J., et al. (2008). Kcnqlotl antisense noncoding RNA mediates lineage-specific transcriptional silencing through chromatin-level regulation. Mol. Cell 32, 232-246. doi: 10.1016/j.molcel.2008.08.022

Park, S. -W., Kuroda, M. I., and Park, Y. (2008). Regulation of histone H4 Lys16 acetylation by predicted alternative secondary structures in roX noncoding RNAs. Mol. Cell. Biol. 28, 4952-4962. doi: 10.1128/mcb.00 219-08

Peng, W., and Feng, J. (2016). Long noncoding RNA LUNAR1 associates with cell proliferation and predicts a poor prognosis in diffuse large B-cell lymphoma. Biomed. Pharmacother. 77, 65-71. doi: 10.1016/j.biopha.2015.12.001

Penny, G. D., Kay, G. F., Sheardown, S. A., Rastan, S., and Brockdorff, N. (1996). Requirement for Xist in X chromosome inactivation. Nature 379, 131-137. doi: 10.1038/379131a0

Pintacuda, G., Wei, G., Roustan, C., Kirmizitas, B. A., Solcan, N., Cerase, A., et al. (2017). hnRNPK recruits PCGF3/5-PRC1 to the Xist RNA B-repeat to establish polycomb-mediated chromosomal silencing. Mol. Cell 68, 955.e10-969.e10. doi: 10.1016/j.molcel.2017.11.013

Plath, K., Fang, J., Mlynarczyk-Evans, S. K., Cao, R., Worringer, K. A., Wang, H., et al. (2003). Role of histone $\mathrm{H} 3$ lysine 27 methylation in $\mathrm{X}$ inactivation. Science 300, 131-135. doi: 10.1126/science.1084274

Ponjavic, J., Ponting, C. P., and Lunter, G. (2007). Functionality or transcriptional noise? Evidence for selection within long noncoding RNAs. Genome Res. 17, 556-565. doi: 10.1101/gr.6036807

Portoso, M., Ragazzini, R., Brenčič, Ž., Moiani, A., Michaud, A., Vassilev, I., et al. (2017). PRC2 is dispensable for HOTAIR-mediated transcriptional repression. ЕMBO J. 36, 981-994. doi: 10.15252/embj.201695335

Postepska-Igielska, A., Giwojna, A., Gasri-Plotnitsky, L., Schmitt, N., Dold, A., Ginsberg, D., et al. (2015). LncRNA Khps1 regulates expression of the proto-oncogene SPHK1 via triplex-mediated changes in chromatin structure. Mol. Cell 60, 626-636. doi: 10.1016/j.molcel.2015.10.001

Postepska-Igielska, A., Krunic, D., Schmitt, N., Greulich-Bode, K. M., Boukamp, P., and Grummt, I. (2013). The chromatin remodelling complex NoRC safeguards genome stability by heterochromatin formation at telomeres and centromeres. EMBO Rep. 14, 704-710. doi: 10.1038/embor.2013.87

Quinn, J. J., Zhang, Q. C., Georgiev, P., Ilik, I. A., Akhtar, A., and Chang, H. Y. (2016). Rapid evolutionary turnover underlies conserved lncRNA-genome interactions. Genes Dev. 30, 191-207. doi: 10.1101/gad.272187.115

Ramírez, F., Lingg, T., Toscano, S., Lam, K. C., Georgiev, P., Chung, H. -R., et al. (2015). High-affinity sites form an interaction network to facilitate spreading of the MSL complex across the $\mathrm{X}$ chromosome in Drosophila. Mol. Cell 60, 146-162. doi: 10.1016/j.molcel.2015.08.024

Rao, S. S. P., Huntley, M. H., Durand, N. C., Stamenova, E. K., Bochkov, I. D., Robinson, J. T., et al. (2014). A 3D map of the human genome at kilobase resolution reveals principles of chromatin looping. Cell 159, 1665-1680. doi: 10.1016/j.cell.2014.11.021

Rinn, J. L., and Chang, H. Y. (2012). Genome regulation by long noncoding RNAs. Annu. Rev. Biochem. 81, 145-166. doi: 10.1146/annurevbiochem-051410-092902

Rinn, J. L., Kertesz, M., Wang, J. K., Squazzo, S. L., Xu, X., Brugmann, S. A., et al. (2007). Functional demarcation of active and silent chromatin domains in human HOX loci by noncoding RNAs. Cell 129, 1311-1323. doi: 10.1016/j. cell.2007.05.022

Rivas, E., Clements, J., and Eddy, S. R. (2017). A statistical test for conserved RNA structure shows lack of evidence for structure in lncRNAs. Nat. Methods 14, 45-48. doi: 10.1038/nmeth.4066

Rivas, E., Clements, J., and Eddy, S. R. (2020). Estimating the power of sequence covariation for detecting conserved RNA structure. Bioinformatics 36, 3072-3076. doi: 10.1093/bioinformatics/btaa080

Santoro, F., Mayer, D., Klement, R. M., Warczok, K. E., Stukalov, A., Barlow, D. P., et al. (2013). Imprinted Igf2r silencing depends on continuous Airn lncRNA expression and is not restricted to a developmental window. Development 140, 1184-1195. doi: 10.1242/dev.088849

Santoro, R., Schmitz, K. -M., Sandoval, J., and Grummt, I. (2010). Intergenic transcripts originating from a subclass of ribosomal DNA repeats silence ribosomal RNA genes in trans. EMBO Rep. 11, 52-58. doi: 10.1038/embor.2009.254

Sarma, K., Cifuentes-Rojas, C., Ergun, A., Del Rosario, A., Jeon, Y., White, F., et al. (2014). ATRX directs binding of PRC2 to Xist RNA and Polycomb targets. Cell 159, 869-883. doi: 10.1016/j.cell.2014.10.019

Savić, N., Bär, D., Leone, S., Frommel, S. C., Weber, F. A., Vollenweider, E., et al. (2014). IncRNA maturation to initiate heterochromatin formation in the nucleolus is required for exit from pluripotency in ESCs. Cell Stem Cell 15, 720-734. doi: 10.1016/j.stem.2014.10.005

Saxena, A., and Carninci, P. (2011). Long non-coding RNA modifies chromatin: epigenetic silencing by long non-coding RNAs. Bioessays 33, 830-839. doi: 10.1002/bies.201100084

Schmitt, A. M., and Chang, H. Y. (2016). Long noncoding RNAs in cancer pathways. Cancer Cell 29, 452-463. doi: 10.1016/j.ccell.2016.03.010

Schmitz, K. -M., Mayer, C., Postepska, A., and Grummt, I. (2010). Interaction of noncoding RNA with the rDNA promoter mediates recruitment of DNMT3b and silencing of rRNA genes. Genes Dev. 24, 2264-2269. doi: $10.1101 / \operatorname{gad} .590910$

Schoeftner, S., and Blasco, M. A. (2008). Developmentally regulated transcription of mammalian telomeres by DNA-dependent RNA polymerase II. Nat. Cell Biol. 10, 228-236. doi: 10.1038/ncb1685

Schoenfelder, S., and Fraser, P. (2019). Long-range enhancer-promoter contacts in gene expression control. Nat. Rev. Genet. 20, 437-455. doi: 10.1038/ s41576-019-0128-0

Schorderet, P., and Duboule, D. (2011). Structural and functional differences in the long non-coding RNA hotair in mouse and human. PLoS Genet. 7:e1002071. doi: 10.1371/journal.pgen.1002071

Seidl, C. I. M., Stricker, S. H., and Barlow, D. P. (2006). The imprinted air ncRNA is an atypical RNAPII transcript that evades splicing and escapes nuclear export. EMBO J. 25, 3565-3575. doi: 10.1038/sj.emboj.7601245

Shi, Y., Downes, M., Xie, W., Kao, H. Y., Ordentlich, P., Tsai, C. C., et al. (2001). Sharp, an inducible cofactor that integrates nuclear receptor repression and activation. Genes Dev. 15, 1140-1151. doi: 10.1101/gad.871201

Simon, M. D., Pinter, S. F., Fang, R., Sarma, K., Rutenberg-Schoenberg, M., Bowman, S. K., et al. (2013). High-resolution Xist binding maps reveal two-step spreading during X-chromosome inactivation. Nature 504, 465-469. doi: $10.1038 /$ nature 12719

Sleutels, F., Zwart, R., and Barlow, D. P. (2002). The non-coding air RNA is required for silencing autosomal imprinted genes. Nature 415, 810-813. doi: $10.1038 / 415810 \mathrm{a}$

Smith, M. A., Gesell, T., Stadler, P. F., and Mattick, J. S. (2013). Widespread purifying selection on RNA structure in mammals. Nucleic Acids Res. 41, 8220-8236. doi: 10.1093/nar/gkt596

Somarowthu, S., Legiewicz, M., Chillón, I., Marcia, M., Liu, F., and Pyle, A. M. (2015). HOTAIR forms an intricate and modular secondary structure. Mol. Cell 58, 353-361. doi: 10.1016/j.molcel.2015.03.006

Sridhar, B., Rivas-Astroza, M., Nguyen, T. C., Chen, W., Yan, Z., Cao, X., et al. (2017). Systematic mapping of RNA-chromatin interactions in vivo. Curr. Biol. 27, 602-609. doi: 10.1016/j.cub.2017.01.011 
Stelzer, Y., Sagi, I., Yanuka, O., Eiges, R., and Benvenisty, N. (2014). The noncoding RNA IPW regulates the imprinted DLK1-DIO3 locus in an induced pluripotent stem cell model of Prader-Willi syndrome. Nat. Genet. 46, 551-557. doi: 10.1038/ng.2968

Tavares, R. C. A., Pyle, A. M., and Somarowthu, S. (2019). Phylogenetic analysis with improved parameters reveals conservation in lncRNA structures. J. Mol. Biol. 431, 1592-1603. doi: 10.1016/j.jmb.2019.03.012

Tomita, S., Abdalla, M. O. A., Fujiwara, S., Matsumori, H., Maehara, K., Ohkawa, Y., et al. (2015). A cluster of noncoding RNAs activates the ESR1 locus during breast cancer adaptation. Nat. Commun. 6:6966. doi: 10.1038/ncomms7966

Trimarchi, T., Bilal, E., Ntziachristos, P., Fabbri, G., Dalla-Favera, R., Tsirigos, A., et al. (2014). Genome-wide mapping and characterization of notch-regulated long noncoding RNAs in acute leukemia. Cell 158, 593-606. doi: 10.1016/j. cell.2014.05.049

Tripathi, V., Ellis, J. D., Shen, Z., Song, D. Y., Pan, Q., Watt, A. T., et al. (2010). The nuclear-retained noncoding RNA MALAT1 regulates alternative splicing by modulating SR splicing factor phosphorylation. Mol. Cell 39, 925-938. doi: 10.1016/j.molcel.2010.08.011

Tsai, M. -C., Manor, O., Wan, Y., Mosammaparast, N., Wang, J. K., Lan, F., et al. (2010). Long noncoding RNA as modular scaffold of histone modification complexes. Science 329, 689-693. doi: 10.1126/science.1192002

Ulitsky, I. (2016). Evolution to the rescue: using comparative genomics to understand long non-coding RNAs. Nat. Rev. Genet. 17, 601-614. doi: 10.1038/nrg.2016.85

Ulitsky, I., Shkumatava, A., Jan, C. H., Sive, H., and Bartel, D. P. (2011). Conserved function of lincRNAs in vertebrate embryonic development despite rapid sequence evolution. Cell 147, 1537-1550. doi: 10.1016/j.cell.2011.11.055

van Bakel, H., Nislow, C., Blencowe, B. J., and Hughes, T. R. (2010). Most "dark matter" transcripts are associated with known genes. PLoS Biol. 8:e1000371. doi: 10.1371/journal.pbio.1000371

van Bemmel, J. G., Galupa, R., Gard, C., Servant, N., Picard, C., Davies, J., et al. (2019). The bipartite TAD organization of the X-inactivation center ensures opposing developmental regulation of Tsix and Xist. Nat. Genet. 51, 1024-1034. doi: 10.1038/s41588-019-0412-0

Wang, K. C., and Chang, H. Y. (2011). Molecular mechanisms of long noncoding RNAs. Mol. Cell 43, 904-914. doi: 10.1016/j.molcel.2011.08.018

Wang, F., Tang, Z., Shao, H., Guo, J., Tan, T., Dong, Y., et al. (2018). Long noncoding RNA HOTTIP cooperates with CCCTC-binding factor to coordinate HOXA gene expression. Biochem. Biophys. Res. Commun. 500, 852-859. doi: 10.1016/j.bbrc.2018.04.173

Wang, K. C., Yang, Y. W., Liu, B., Sanyal, A., Corces-Zimmerman, R., Chen, Y., et al. (2011). A long noncoding RNA maintains active chromatin to coordinate homeotic gene expression. Nature 472, 120-124. doi: 10.1038/nature09819

Wehner, S., Dörrich, A. K., Ciba, P., Wilde, A., and Marz, M. (2014). pRNA: NoRC-associated RNA of rRNA operons. RNA Biol. 11, 3-9. doi: 10.4161/ rna.27448

Wevrick, R., and Francke, U. (1997). An imprinted mouse transcript homologous to the human imprinted in Prader-Willi syndrome (IPW) gene. Hum. Mol. Genet. 6, 325-332. doi: $10.1093 / \mathrm{hmg} / 6.2 .325$

Wevrick, R., Kerns, J. A., and Francke, U. (1994). Identification of a novel paternally expressed gene in the Prader-Willi syndrome region. Hum. Mol. Genet. 3, 1877-1882. doi: $10.1093 / \mathrm{hmg} / 3.10 .1877$

Will, S., Joshi, T., Hofacker, I. L., Stadler, P. F., and Backofen, R. (2012). LocARNA-P: accurate boundary prediction and improved detection of structural RNAs. RNA 18, 900-914. doi: 10.1261/rna.029041.111
Wongtrakoongate, P., Riddick, G., Fucharoen, S., and Felsenfeld, G. (2015). Association of the long non-coding RNA steroid receptor RNA activator (SRA) with TrxG and PRC2 complexes. PLoS Genet. 11:e1005615. doi: 10.1371/journal.pgen.1005615

Wutz, A., and Jaenisch, R. (2000). A shift from reversible to irreversible X inactivation is triggered during ES cell differentiation. Mol. Cell 5, 695-705. doi: 10.1016/S1097-2765(00)80248-8

Yang, F., Deng, X., Ma, W., Berletch, J. B., Rabaia, N., Wei, G., et al. (2015). The lncRNA Firre anchors the inactive $\mathrm{X}$ chromosome to the nucleolus by binding CTCF and maintains H3K27me3 methylation. Genome Biol. 16:52. doi: 10.1186/s13059-015-0618-0

Yang, L., Lin, C., Liu, W., Zhang, J., Ohgi, K. A., Grinstein, J. D., et al. (2011). ncRNA- and Pc2 methylation-dependent gene relocation between nuclear structures mediates gene activation programs. Cell 147, 773-788. doi: 10.1016/j. cell.2011.08.054

Yao, H., Brick, K., Evrard, Y., Xiao, T., Camerini-Otero, R. D., and Felsenfeld, G. (2010). Mediation of CTCF transcriptional insulation by DEAD-box RNAbinding protein p68 and steroid receptor RNA activator SRA. Genes Dev. 24, 2543-2555. doi: 10.1101/gad.1967810

Yotova, I. Y., Vlatkovic, I. M., Pauler, F. M., Warczok, K. E., Ambros, P. F., Oshimura, M., et al. (2008). Identification of the human homolog of the imprinted mouse air non-coding RNA. Genomics 92, 464-473. doi: 10.1016/j. ygeno.2008.08.004

Zhang, B., Arun, G., Mao, Y. S., Lazar, Z., Hung, G., Bhattacharjee, G., et al. (2012). The lncRNA Malat1 is dispensable for mouse development but its transcription plays a cis-regulatory role in the adult. Cell Rep. 2, 111-123. doi: 10.1016/j.celrep.2012.06.003

Zhang, H., Zeitz, M. J., Wang, H., Niu, B., Ge, S., Li, W., et al. (2014). Long noncoding RNA-mediated intrachromosomal interactions promote imprinting at the Kcnq1 locus. J. Cell Biol. 204, 61-75. doi: 10.1083/ jcb.201304152

Zhang, A., Zhao, J. C., Kim, J., Fong, K. -W., Yang, Y. A., Chakravarti, D., et al. (2015). LncRNA HOTAIR enhances the androgen-receptor-mediated transcriptional program and drives castration-resistant prostate cancer. Cell Rep. 13, 209-221. doi: 10.1016/j.celrep.2015.08.069

Zhao, X., Patton, J. R., Ghosh, S. K., Fischel-Ghodsian, N., Shen, L., and Spanjaard, R. A. (2007). Pus3p- and Puslp-dependent pseudouridylation of steroid receptor RNA activator controls a functional switch that regulates nuclear receptor signaling. Mol. Endocrinol. 21, 686-699. doi: 10.1210/ me.2006-0414

Zhao, J., Sun, B. K., Erwin, J. A., Song, J. -J., and Lee, J. T. (2008). Polycomb proteins targeted by a short repeat RNA to the mouse X chromosome. Science 322, 750-756. doi: 10.1126/science.1163045

Conflict of Interest: The authors declare that the research was conducted in the absence of any commercial or financial relationships that could be construed as a potential conflict of interest.

Copyright (c) 2020 Ramirez-Colmenero, Oktaba and Fernandez-Valverde. This is an open-access article distributed under the terms of the Creative Commons Attribution License (CC BY). The use, distribution or reproduction in other forums is permitted, provided the original author(s) and the copyright owner(s) are credited and that the original publication in this journal is cited, in accordance with accepted academic practice. No use, distribution or reproduction is permitted which does not comply with these terms. 